\title{
If Culture Is Software Of The Mind, Then Ours Needs An Upgrade: Lamentations On Our Illiteracy Of African Business And Culture
}

Brent Smith, Saint Joseph's University, USA

\begin{abstract}
Acknowledging culture as the "software of the mind" (Hofstede, 1994), this paper asserts that international business, management, and marketing scholars have done too little to address the practitioner community's need for a better knowledgebase regarding African cultures. Despite the importance of Africa to the global economy, transnational marketing, and even the prosperity of rising Asian economic powers, scholars have produced little practicable business knowledge on African national cultures. Over the last thirty years, three leading scholarly projects on national culture, including the work of Hofstede, Trompenaars and Hampden-Turner, and the GLOBE Study, have collectively provided empirical data on a total of only twelve African nations. This paper identifies basic deficiencies in the study of African cultures, highlights the impact of those deficiencies to the cultural knowledgebase, and suggests resolutions for upgrading intelligence on key African cultures vital to transnational business interests.
\end{abstract}

Keywords: Africa, national culture, Hofstede, international business, globalization

\section{INTRODUCTION}

ulture is important to many aspects of business life, especially when a business must interface with people, either as customers, employees, suppliers, or stakeholders. M.L. Jones (2007, p. 2)

The African continent is home to over 50 nation-states representing nearly 900 million people, or nearly $13.5 \%$ of the world's population of 6.7 billion. This continent and its member states have been vital to the development, survival, and prosperity of the international, multinational, and global business. As suppliers of petroleum, agriculture, minerals, and labor, Africa has directly and indirectly helped fuel, feed, build, and service the developed and developing world. Alas, despite its unambiguous integration into world markets, Africa remains dramatically obscure to many scholars and practitioners in international business, management, and marketing. While culture has been regarded as the "software of the mind," international business scholarship has contributed little to our contemporary understanding of cultural values within African societies. These contributions are especially dismal by number and scale when compared against the mass of cultural studies of European, North American, and Asian societies.

As the tides of globalization bring an increasingly diverse array of national and private interests to Africa's shores, academic scholarship will have provided only fractured intelligence for foreign businesspersons interacting with their native counterparts from and within the African continent. While many European nations continue to engage Africa on a mix of colonial and post-colonial terms, other nations have sought to establish more holistic business and economic relations throughout the continent. For example, Saudi Arabia, South Korea, China, India, and other such nations seek out Africa today, not just to extract minerals, but also to negotiate agricultural agreements, infrastructure development projects, arms deals, and so forth. 
African nations are also rising in prominence as national brands. According to EastWest Communications, developers of the Nation Brand Perceptions Index, many Africa nations are peered competitively with those of the developed world. For example, across the 200 nations indexed and ranked from 2008, Africa is represented by Ghana $\left(18^{\text {th }}\right.$ overall), Namibia $\left(54^{\text {th }}\right)$, Tunisia $\left(64^{\text {th }}\right)$, Botswana $\left(84^{\text {th }}\right)$, Mali $\left(97^{\text {th }}\right)$, and Malawi $\left(100^{\text {th }}\right)$. Clearly, African nations as brands are achieving greater prominence on the wider global radar.

With the rise of India and China, the rising superpowers known as "the elephant" and "the dragon," scholars have predicted a global shift of attention from the America and Europe towards Africa and Asia. As Asian powers become wealthier and more politically powerful, they will, like their Western predecessors, aim to project their reach and interests abroad, particularly to nearby, resource rich regions like Africa. Although many Asian and African nations have inherited European-styled economies, they are making significant moves to forge their own brands of shared prosperity.

When the United States and Western Europe transitioned from manufacturing to service to knowledge centered economies, their corporate communities increasingly expanded their international operations. They sought new consumer markets in culturally receptive markets. They also established administrative and manufacturing outposts in a host of developing countries where operating costs were lower than in their home markets. Whether and to what extent other nations, such as China and South Korea, adopt these practices, Africa will likely be included in their plans. For example, Tata Group's Nano car or Taj hotels are marketed in Africa and for Africans, representing just one example of industry's paradigm shift towards developing nations and the world's most costconscious consumers.

Figure 1

Summary of African National Cultures Profiled by Leading Researchers

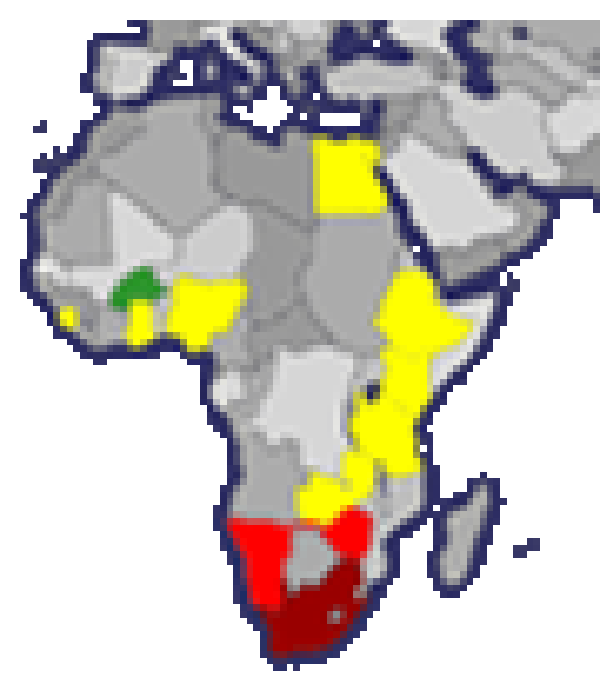

$\begin{array}{lll} & \\ \text { Burkina Faso } & \text { Kenya } & \text { South Africa } \\ \text { Egypt } & \text { Namibia } & \text { Tanzania } \\ \text { Ethiopia } & \text { Nigeria } & \text { Zambia } \\ \text { Ghana } & \text { Sierra Leone } & \text { Zimbabwe }\end{array}$

Hofstede (1980, 2001a)

House et al. (2004)

Trompenaars and Hampden-Turner (1998)

House et al. (2004)

Trompenaars and Hampden-Turner (1998)

Hofstede (1980, 2001a)

House et al. (2004)

Globalization impacts where and how international business and cross-cultural marketing are practiced today. For all intents and purposes, business and marketing (e.g., sales, distribution, service) have become inherently global in scale and scope. In light of this situation, current cross-cultural scholarship seems rather undesirably exposed for its shortcomings in providing informative or instructive guidance that helps international business professionals understand, engage, and cultivate relationships with Africa's corporate, entrepreneurial, and consumer communities. Of all the knowledge developed on the world's national cultures, little is known about how African nations fit into the global community (see Figure 1). 


\section{CULTURE MATTERS}

No matter how hard man tries, it is impossible for him to divest himself of his own culture, for it has penetrated to the roots of his nervous system and determines how he perceives the world ... people cannot act or interact in any meaningful way except through the medium of culture. Edward T. Hall (1966, p.177)

Culture affects how people observe, interpret, perceive, and react to the world around them. Given the diversity of its manifestations and influences, scholars have produced many different definitions of culture. In fact, over five decades ago, Kroeber and Kluckhohn had already cited 164 different definitions of culture (1954, p. 4355). Once demarcated by sacred and secular distinctions, culture was understood in rather nuanced terms. Edward Tylor is attributed with having shifted definitions of culture away from the religious realm towards more secular, intellectual ones. His definition and others' are presented below:

- Edward B. Tylor: Culture is "that complex whole which includes knowledge, belief, art, morals, law, custom, and any other capabilities and habits acquired by man as a member of society." (1871, p. 1)

- Clyde Kluckhohn: "By culture we mean all those historically created designs for living, explicit and implicit, rational, irrational, and nonrational, which exist at any given time as potential guides for the behavior of men." (1945, p. 97)

- Clifford Geertz: "The culture concept...denotes an historically transmitted pattern of meanings embodied in symbols, a system of inherited conceptions expressed in symbolic form by means of which men communicate, perpetuate, and develop their knowledge about and attitudes toward life." (1973, p. 89)

- Louise Damen: "Culture: learned and shared human patterns or models for living; day-to-day living patterns. These patterns and models pervade all aspects of human social interaction. Culture is mankind's primary adaptive mechanism." (1987, p. 387)

While myriad definitions have been proposed, academic and professional adherents in business disciplines generally concentrate their attention on one of two approaches to understanding it - Hall (1976) and Hofstede (1980, 1994, 2001a). The latter is the most widely cited and adopted approach. Aside from these, some attention has been given to the work of Trompenaars and Hampden-Turner (1998) and recently to House et al. (2004). An alternative cultural communication model by Lewis (2005) has also been utilized by international business and policy leaders. Amidst myriad definitions of culture, it is generally agreed that people of the same country tend to have learned a common set of ideas, values, and beliefs which, for them, form culturally specific meaning systems (D'Andrade, 1984). These meaning systems are believed to differentiate national cultures from one another over rather persistently over time (Hofstede, 1980, 1994). Moving beyond the definitions cited above, many cultural researchers have more explicitly integrated values, beliefs, and worldviews. For example:

- Geert Hofstede: "Culture is the collective programming of the human mind that distinguishes the members of one human group from those of another. Culture in this sense is a system of collectively held values." (1991, p. 51)

- $\quad$ L. Kroeber and Clyde Kluckhohn: "Culture consists of patterns, explicit and implicit, of and for behavior acquired and transmitted by symbols, constituting the distinctive achievements of human groups, including their embodiments in artifacts; the essential core of culture consists of traditional (i.e. historically derived and selected) ideas and especially their attached values; culture systems may, on the one hand, be considered as products of action, and on the other as conditioning elements of further action." (1954, p. 181)

By even the most conservative estimates, Hofstede (1980, 1994, and 2001a) has produced the mostly widely accepted and adopted view of culture. With his first study of cultural values within IBM, a globally renowned and leading multinational corporation, Hofstede (1980) initiated the modern world's single most comprehensive research study of national cultures. He identified four dimensions of national cultural orientation, including (1) individualism, (2) power distance, (3) uncertainty avoidance, and (4) masculinity/femininity. Later, Hofstede and Bond (1988) added a fifth dimension, known as long term orientation or Confucian dynamism, to acknowledge how East Asian temperaments of uncertainty avoidance. These dimensions have been applied in cultural research across national, organizational, community, and individual contexts. For example, they have been 
used to explain situations in leadership, management, foreign direct investment, international marketing, logistics, and so forth.

\section{FILE NOT FOUND: INTERNATIONAL BUSINESS SCHOLARSHIP ON AFRICAN CULTURES}

Hofstede's work became a dominant influence and set a fruitful agenda. There is perhaps no other contemporary framework in the general field of "culture and business" that is so general, so broad, so alluring.

Malcolm Chapman (1997, p. 18-19)

Business scholars and practitioners alike agree that culture performs a powerful role in determining how people in society perceive and react to the world around them. Many books, research articles, forums, and workshops have been dedicated to the topic of culture. Business scholars often consider how culture distinguishes organizational cultures, management styles, and consumption behaviors of the world's societies. For example, Kast and Rosenweig (1985) assert that "organizational systems are cultural answers to the problems encountered by humans in achieving their collective ends" (p. 589). With the rise of the multinational corporation, business practitioners relied heavily upon the work of these scholars to help direct or calibrate their own work performances with their colleagues, subordinates, and customers. Now, in the age of the transnational corporation and globalization, more business practitioners, especially those not from the West, require an updated knowledgebase on national cultures, especially the less studied ones outside of the West.

Despite the popularity and utility of his 5-dimensional model of national culture, Hofstede (2001b) laments through critique and admonition that cross-cultural scholars have been "caught up in the straitjacket of my model, and therefore unlikely to make basic new contributions". While he provided the activation energy for contemporary cultural research, he has been hopeful that his adherents and critics would advance his work more creatively and expansively. In particular, he has expressed concern about the need to understand how cultural values are manifest in the nations and societies of the developing world not included in his landmark study. These nations would include, for example, those with ethnically diverse societies throughout Africa, Asia, and South America.

In his lamentation, Hofstede suggests that "respectable research reports end with a call for more research, and in my case such a call is absolutely essential" since his initial work thus far has "has produced unfinished business" (Hofstede, 2001b). Responding to his own call, he identifies several steps which should be taken to liberate ourselves from his figurative straitjacket and further our understanding of national cultures beyond the ones which account for most existing research (Note: Hofstede's indices of national cultures currently represent nearly 70 national cultures, of which only 8 are definitively African, including South Africa plus two clusters of East African and West African nations. Lewis (2005) categorizes Black African cultures into a single group. House et al. (2004) indexes 62 national cultures, of which only 8 are African).

Of the many steps Hofstede (2001b) provided nearly eight years ago, the following selections illuminate the fact that international business and marketing professionals still lack a meaningful knowledgebase of disciplined scholarship on how to understand, distinguish, and interact with African cultures. Hofstede (2001b) asserts:

1. The concept of dimensions of national culture ... should be further underpinned, criticized, and complemented ... by exposure to the comments of scholars and practitioners from a variety of national backgrounds.

2. The set of countries covered should be expanded from the present 40 to include others as well - the Socialist world, the smaller Third World countries. Eventually it should include all except the very small countries.

3. The analysis of differences in national cultures should be complemented with a further differentiation of regional, ethnic, occupational, and organizational subcultures.

4. Beyond the consequences for policy - that is, for practice - the cultural relativism which my findings support calls for an effort at theory-building, especially in those countries in which theories of modern man, management, organization, and society must be imported wholesale from abroad. In the past 30 years there has been altogether too much reliance on American-made management and theories for countries in which neither the societal conditions nor the mental programming of the population were similar to those in the 
United States. There is a great lack of locally valid theories of management and organization in which the universally human, the globally imposed, and the culturally specific elements will be widely recognized.

\section{CULTURAL LITERACY IN THE INTERNATIONAL BUSINESS CLASSROOM}

Lest those islands still seem to you too remote in space and time to be relevant to our modern societies, just think about the risks... of our increasing globalization and increasing worldwide economic interdependence.

Jared Diamond, Geographer and Pulitzer Prize Winner

The corporate community needs business schools to train students who are professionally competent and culturally literate. Despite the existence of myriad published research about the rising prominence of African competitiveness and nation brands, very few business journals, texts, and media provide much educational utility for people interested in doing business with Africa. The World Economic Forum's Global Competitiveness Index and Africa Competitiveness Report, published annually since 2000, profiles the top 30 North African and Sub-Saharan African nations (see Table 1 for countries listed in 2008-2009 report). Unfortunately, few business students have been made familiar with the names, locations, resources, or cultures of these nations. Even worse, this problem is dramatically compounded by the fact that too few business scholars and educators possess truly adequate cultural literacy or international experiences that could make students appreciate the importance of African business, industry, and society to the global competitiveness of American, European, or Asian firms. Saudi Arabia, India, South Korea, and China have embarked on a wide range agricultural, energy, infrastructure, weapons, and other deals with African nations and companies. Hence, their industry professionals and policy leaders have a demand for cultural knowledgebase that includes values-oriented insights about how to approach African managers, consumers, and markets.

\section{A Hypothetical Scenario}

Accordingly, globalization is not only something that will concern and threaten us in the future, but something that is taking place in the present and to which we must first open our eyes. Ulrich Beck, Sociologist

Suppose that a young, enterprising marketing student from China, Brazil, or US has been urged to think beyond the borders of her own country. In its mission, her business school stresses the importance of diversity and globalization in today's business education. This student matriculates through the business administration major with a specialization in international marketing and several courses in the general liberal arts curriculum. She is informed by professors and periodicals that she should appreciate the diversity of the world's nearly 6.4 billion people not sharing her national heritage and cultural values. Her professors probably discuss how culture plays a formative role in shaping how consumers perceive, interpret, and respond to the world around them. Indeed, she learns that international business researchers and consultants actually contemplate how certain values and practices actually distinguish national cultures from one another. She recalls from her management, international business, and global marketing textbooks that culture is widely accepted as the "software of the mind" (Hofstede, 1991). She finds this descriptive analogy quite interesting and easy to comprehend. Fascinated by this analogy, she reads more, learning that culture can be regarded as the "collective programming of the mind which distinguished the members of one human group from another" (Hofstede, 1991). She studies an extensive listing of nations and their associated cultural values only to discover that there's little to satisfy her curiosity about the 50-plus nations in Africa.

This scenario is hardly atypical. Too seldom do business schools, their curricula, or their faculty earnestly incorporate the African continent, African cultures, or African industry into their themes on diversity and globalization. But, if scholarship is intended to inform the quality of teaching, then might business schools be deficient in broadening the worldview of the students whom they exhort to "think globally"? Further, if business scholars look to the academy for relevant and up-to-date knowledge, then might they be unimpressed with the collective cultural illiteracy on how to do business with African managers, colleagues, and customers? How long will American and European organizations act as culturally distant and ignorant spectators, while the Indians, Chinese, Koreans, and Saudis attempt to crowd out future Western participation? In light of these plausible events, how might culturally-oriented scholars respond and temper future outcomes? 


\section{RESOLUTIONS: APPLYING PATCHES OR UPGRADES TO THE SOFTWARE}

The first step to resolving a problem involves acknowledging the problem, as this paper has done. As with most social problems, the collective ignorance of Africa and its cultures affects more than just business scholars. It affects business educators, business students, and global business professionals.

\section{Acknowledging the Problem}

Cross-cultural marketers have been made familiar with conventional practices gone wrong, such as Gerber's placement of baby's image on food labels. But, how many of these accidents still happen today and will continue to happen in the future without a proper regard for Africa's diverse, yet coherent cultures. Scores of civilizations, conflicts, and agreements between different peoples with different "software of the mind" has led us to appreciate the fact that Europe is not a monolith. All Europeans are not and have never been fully alike, save being inhabitants of the large contiguous land mass on which they live. These same facts hold true for Africans and the African continent, yet management, marketing, and other cultural researchers have irresponsibly glazed over African cultures in purely monolithic, regional, or racial terms (McSweeney, 2009).

Multinational and transnational organizations, operating within a globalized environment, often consult the opinion of cultural experts from scholarly and practitioner circles. Likewise, business students depend on their professors and textbooks assigned for course reading in order to obtain basic facts and information about people, places, and issues involved in global business. The scholars, professors, and practitioners directing their business clients and students logically temper their guidance based on some mixture of their own direct experience and working knowledge along with knowledge shared by colleagues in related disciplines.

\section{Hofstede's Lamentation as a Turning Point}

Hofstede (2001b) provides a useful starting point for increasing and improving business-ready knowledge of African cultures. This starting point represents an effective foundation for resolving the collective ignorance of African cultures among international business academics and practitioners.

Much like Bill Gates, designer of Microsoft Windows, the world's leading operating system on personal computers, Hofstede, is the developer of the world's most renowned taxonomy of national cultural values, or the "collective programming of the mind". Just as Microsoft has acknowledged the need to issue upgrades and patches to its software, likewise Hofstede has done the same regarding the "software of the mind". While his approach has been duly criticized for some of its imperfections, it has proven thus far durable and insightful across many business contexts. Acknowledging the lamentations of Hofstede (2001b), scholars must consider whether their own programming biases their conceptualizations of culture in general, and African cultures, in particular. In keeping with the "software of the mind" metaphor, if one must contemplate issues of compatibility. This would be analogous to attempting to run user-friendly Mac programs on Microsoft Vista. While user-friendliness is attractive, the point is a moot one, since Vista does not run programs written for the Mac platform. Hence, we must work towards understanding African culture in ways that allow for replacements or adjuncts to Hofstede's dimensions. That is, we should not acculturate, or assimilate, descriptions of African culture into the neat, existing software code designed to describe the Western cultures that predominate current management knowledge in the field.

\section{Where to Start: Globally Competitive African Nations}

The nearly 30 nations featured in the World Economic Forum's Africa Competitiveness Report provide a starting point for business and management scholars to pick up where Hofstede stopped (see Table 1). These nations represent viable prospects for nations and corporations currently operating or planning to enter African markets. From 2001 to 2008, GDP growth for the African continent has average 5.9 percent annually. Foreign direct investment has doubled from 2003 to 2007 (UNCTAD, FDISTAT, 2008).

The people of African nations, despite decades of colonization and artificial border creations by foreign powers, have retained much of their own identities. As alluded by Hofstede, the people of these nations live within 
and even straddle African nation-states which have their own distinct, non-Anglo-Saxon cultural meaning systems (Point 1). Further, many of these cultures comprise parts of the so-called Third World (Point 2), account for greater than one million people within (Point 2), and represent myriad ethnicities and occupational cultures not considered in the landmark or replicated research of Hofstede (1980), Trompenaars and Hampden-Turner (1998), and others (Point 4). Moreover, while they have inherited elements of Western capitalism, they have not relied upon Western borne or tailored management theories (Point 4). Finally, these cultures identify with mental programming and societal conditions that are dramatically different from those of their Western counterparts (Point 4) (Lassiter, 1999).

\section{How to Observe African Cultures: Eyes of the Beholder}

South Africa, the most prosperous national society of the African continent has been an easy, and, consequently, common context for examining African cultures (see Trompenaars and Hampden-Turner, 1998; Lewis, 2005). Hence, it provides a good basis for understanding conventional issues and errors in examining African cultures. South Africa has a majority Black population, but it is still quite diverse, comprised of people with European and Asian ancestry as well. Ironically, however, Beukman (2005) observes, "Cultures of many organizations are still ignoring the fact the largest proportion of the population is African, and not European or American" (p. 58). While directed at scholars of South African culture, this observation illuminates a broader issue. First, the prevailing definitions and descriptions culture have, to date, originated from European or American perspective. Second, these definitions and description may preclude both scholars and practitioners from actually comprehending the core characteristics of African cultures. That is, it may not be appropriate to assume that African cultures can, or should, be interpreted according to the dimensional views of Hofstede or other scholars. Even Hofstede himself presents this admonition. While European and European-influenced cultures may exude values along the lines drawn by Hofstede, African cultural values may exist on an altogether different plane (Lassiter, 1999).

Underscoring these issues, Alcoff (1995) notes that cultural scholarship regarding Africa may be biased by the Eurocentric worldviews, and consequent constructs (e.g., Hall, Hofstede), that have dominated the field. Alas, management scholars have generally treated the carved plural African cultures in a more singular sense as African culture. Or, they implemented a hybrid approach, carving African cultures into different molds on racial or regional bases. For example, in the Lewis (2005) text When Cultures Collide: Leading Across Cultures, only Black South Africans comprise the description of African or sub-Saharan cultures. Lewis (2005) and Hofstede (1980, 2001a) technically exclude Egypt and North African nations from Africa and cluster it with the 'Arab World'. Furthermore, Hofstede (1980, 2001a) clusters Ghana, Nigeria, and Sierra Leone in the 'East Africa' cluster, and Ethiopia, Kenya, Tanzania, and Zambia into the 'West Africa' cluster (see Table 1). Such approaches defy the wisdom of Alcoff (1995), who contends that more cultural research must be led, or at least interpreted by, people belonging to the respective culture(s) being studied. Since current published analyses of African culture(s) have been predominated by Europeans, future resolutions require better regard for Alcoff's call.

Finally, the cultures of all nations within the African continent should be studied as African, rather than parsed on imperially divisive bases of race, ethnicity, and religion. Morocco, Egypt, Tunisia, Algeria, and other nations are African nations. Violations of this fact have become a convention unto themselves, dominated largely by non-African scholars. European nations, eastern and western, are studied as members of the European continent. The same generally holds true for Asian, South American, and North American nations as well. Hence, the continental standard ought to be maintained uniformly in research applications. 
Table 1

African National Cultures Profiled in National Cultural Research

Note: Nations appear in the Africa Competitiveness Report (World Economic Forum, 2008)

Hofstede

North Africa
Algeria
Egypt
Libya
Morocco
Tunisia

Sub-Saharan Africa

Benin

Burkina Faso

Burundi

Cameroon

Chad

Côte d'Ivoire

Ethiopia

Gambia, The

Ghana

Kenya

Lesotho

Madagascar

Malawi

Mali

Mauritania

Mauritius

Mozambique

Namibia

Nigeria

Senegal

South Africa

Tanzania

Uganda

Zambia

Zimbabwe

$\mathrm{x}$

$\mathrm{x}$

$\mathrm{X}$

$\mathrm{x}$
House et al.
(GLOBE Study)

Lewis
Trompenaars Hampden-Turner $\mathrm{x}$

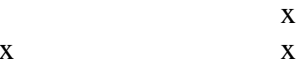

$\mathrm{X}$

$\mathrm{x}$

$x-2$

$\mathrm{x}$ $\mathrm{x}$

$\mathrm{X}$

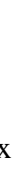

$\mathrm{x}$

$\mathrm{x}$

Total African Nations

8

7

4

\section{CONCLUSION}

Basic knowledge of culture is required of any respectable international business scholar or professionals. Debate persists about the best approaches for understanding and comparing national or societal cultures (Tayeb, 2001; McSweeney, 2002; Hofstede, 2001b). However, that debate cannot trump the need for non-monolithic scholarship about the cultures of African societies. In the new millennium, it should not make us lose sight of the fact that business academics, students, and managers know far too little about Africa - home to 900 million people, key global shipping channels, vital natural resources, the world's largest desert, the world's longest river. In the words of Peter Brabeck-Letmathe, Chairman and CEO of Nestlé, "What we [...] can do is help draw attention to the emerging African success story" (2006).

Globalization continue to prompt academic, business, and even diplomatic communities to gather a better understanding of non-Western cultures, particularly those of the African continent. As more commercial interests from India, China, South Korea, and Saudi Arabia pursue market-oriented exchanges with African counterparts, 
they will demand from academics better cultural knowledge and expertise than what currently exists today. That cultural knowledge and expertise must reflect proper literacy of a diverse Africa comprised of Kenya, Ethiopia, Equatorial Guinea, Nigeria, Swaziland, Zimbabwe, and other individual African nations, not merely trite regional or racial clusters. Sino-African relations have already produced significant negotiations on matters of petroleum, road construction, and mining. South Korea and Saudi Arabia have entered long-term agricultural agreements with Madagascar and Ethiopia, respectively. So, while Africa's understudied nations do business with Near, South, and East Asia, it is imperative that we contemplate more seriously the software that guides their collective minds.

\section{AUTHOR INFORMATION}

Brent Smith is Assistant Professor of Marketing in the Erivan K. Haub School of Business at Saint Joseph's University (Philadelphia, Pennsylvania). His teaching and research interests include international marketing, marketing strategy, and marketing ethics.

\section{REFERENCES}

1. Alcoff, L. (1995). The Problem of Speaking for Others. in Roof, J. and Wiegman, R. (eds.), Who Can Speak? Authority and Critical Identity. Urbana, IL: University of Illinois Press.

2. Brabeck-Letmathe, P. (2006). 18 Months after the Commission for Africa: What Can Business Deliver in Africa? (Speech), International Business Leaders Programme, November $7^{\text {th }}$ at Chatham House, London, England.

3. Chapman, M. (1997). Preface: Social Anthropology, Business Studies, and Cultural Issues, International Studies in Management \& Organization, 26(4), 3-29.

4. Damen, L. (1987). Culture Learning: The Fifth Dimension on the Language Classroom, Reading, MA: Addison-Wesley.

5. D'Andrade, R.G. (1984). Cultural Meaning Systems, in Cultural Theory: Essays on Mind, Self, and Emotion, R. A. Shweder and R. A. LeVine, eds., Cambridge University Press, Cambridge, UK, 88-119.

6. EastWest Communications (2009). Nation Brands Perception Index.

7. Geertz, C. (1973). The Interpretation of Cultures, Harper Collins, New York.

8. Hall, E.T. (1966). The Hidden Dimension, Garden City, NY: Doubleday.

9. Hall, E.T. (1976). Beyond Culture, NY: Anchor Press/Doubleday.

10. Hofstede, G. (1980). Culture's Consequences: International Differences in Work-related Values, Newbury Park: Sage Publications.

11. Hofstede, G. (1991). National Cultures and Corporate Cultures, in Communication between Cultures, ed. Larry A. Samovar and Richard E. Porter Belmont, CA: Wadsworth.

12. Hofstede, G. (1994). Cultures and Organizations: Software of the Mind: Intercultural Cooperation and its Importance for Survival, London, England: Harper Collins Business.

13. Hofstede, G. (1997). Culture and Organizations: Software of the Mind. New York, NY: The McGraw Hill Companies, Inc.

14. Hofstede, G. (2001a). Culture's Consequences: Comparing Values, Behaviors, Institutions and Organizations across Nations ( $2^{\text {nd }}$ ed.). Thousand Oaks, CA: Sage Publications.

15. Hofstede, G. (2001b). “Culture's Recent Consequences: Using Dimensions Scores in Theory and Research,” International Journal of Cross-Cultural Management, 1 (1): 11-17.

16. Hofstede, G. \& M. H. Bond (1988). The Confucius Connection: From Cultural Roots to Economic Growth, Organizational Dynamics 16(4): 5-21.

17. Hofstede, G. (2009). Geert Hofstede Cultural Dimensions. Available at: http://www.geerthofstede.com/hofstede dimensions.php.

18. House, R.J., P.J. Hanges, M. Javidan, P.W. Dorfman, \& V. Gupta (2004). Culture, Leadership, and Organizations: The GLOBE Study of 62 Societies. Thousand Oaks, CA: Sage Publications.

19. Jones, M. (2007). Hofstede - Culturally Questionable? Oxford Business \& Economics Conference, 24-26 June, Oxford, UK.

20. Kluckhohn, C. (1945). The Concept of Culture, in The Science of Man in the World Crisis, ed. Ralph Linton, New York, NY: Columbia University Press. 
21. Kroeber, A., \& Kluckhohn, C. (1954). Culture: A Critical Review of Concepts and Definitions. New York, NY: Random House.

22. Lassiter, J.E. (1999). Bad Social Science, Effective Social Activism, or a Call to Reinvent Ethnology? African Culture and Personality 3 (2):1.

23. Lewis, R. (2005). When Cultures Collide: Leading Across Cultures, Boston, MA: Nicholas Brealey Publishing.

24. Mcsweeney, B. (2002). Hofstede's Model of National Cultural Differences and Their Consequences: A Triumph of Faith - A Failure of Analysis. Human Relations 55 (1): 89-118.

25. Tayeb, M. (2001). Conducting Research across Cultures: Overcoming Drawbacks and Obstacles, International Journal of Cross Cultural Management, Vol. 1: 91-108.

26. Tylor, E.B. (1871). Primitive Culture, London, England: J. Murray.

27. Trompenaars, F. \& Hampden-Turner, C. (1998). Riding the Waves of Culture: Understanding Cultural Diversity in Business, New York, NY: McGraw-Hill.

28. World Economic Forum (2009). Global Competitiveness Report 2009.

29. World Economic Forum (2009). Africa Competitiveness Report 2009. 